\title{
Scoping Review: Pengaruh Bensin terhadap Peningkatan Kadar LDL pada Plasma Darah Tikus
}

\author{
Yola Noveraz Nasa, ${ }^{1}$ Nugraha Sutadipura, ${ }^{2}$ Santun Bhekti Rahimah ${ }^{3}$ \\ ${ }^{1}$ Prodi Pendidikan Dokter, Fakultas Kedokteran Universitas Islam Bandung, \\ ${ }^{2}$ Departmen Biokimia, Fakultas Kedokteran Universitas Islam Bandung, \\ 3Departmen Farmakologi, Fakultas Kedokteran Universitas Islam Bandung
}

\begin{abstract}
Abstrak
Konsumsi bensin sejak tahun 2000 sampai 2014 meningkat seiring dengan peningkatan jumlah kendaraan bermotor setiap tahun. Bensin memiliki dampak negatif terhadap lingkungan berupa polusi dan terhadap kesehatan seperti gangguan paru, ginjal, penyakit kulit, serta perubahan profil lipid berupa peningkatan kadar low-density lipoprotein (LDL) yang dapat meningkatkan angka kejadian penyakit jantung koroner dan sindrom metabolik. Tujuan penelitian mengetahui pengaruh paparan bensin terhadap kadar LDL pada plasma darah manusia yang dimulai dengan kajian terhadap hewan coba. Metode penelitian yang digunakan yaitu deskriptif dengan prosedur scoping review dengan cara mengidentifikasi, menganalisis dan mengevaluasi karya ilmiah sesuai dengan kriteria inklusi dan eksklusi serta diskrining menggunakan kriteria kelayakan (Eligibility criteria). Hasil penelitian didapatkan sepuluh artikel dari jumlah awal 10.486 artikel yang ditemukan dari kata kunci. Sepuluh artikel yang sesuai dengan PICO (Population: tikus; Intervention: bensin, lead atau benzene; Comparison: tikus yang tidak dipaparkan bensin, lead atau benzene; Outcome: kadar LDL pada plasma darah) menunjukkan peningkatan kadar LDL plasma pada kelompok tikus yang diberi paparan bensin, timbal atau benzena daripada kelompok kontrol. Hal tersebut diakibatkan stres oksidatif dari induksi lead atau benzene yang menekan aktivitas antioksidan dan meningkatkan reactive oxygen species di tubuh sehingga terjadi cidera hepar dan metabolisme lipoproteinpun terganggu. Pada akhirnya bensin yang memiliki komponen benzene atau lead mengakibatkan peningkatan kadar LDL plasma. Kesimpulan penelitian terdapat pengaruh bensin terhadap kadar LDL pada plasma darah tikus dan beberapa komponen bensin yang berperan, yaitu timbal dan benzena.
\end{abstract}

Kata kunci: Bensin, benzena, low-density lipoprotein, timbal

\section{Scoping Review: Effect of Gasoline on Increasing Blood Plasma LDL Levels in Rats}

\begin{abstract}
Gasoline consumption from 2000 to 2014 increased along with the increase in the number of motorized vehicles each year. Gasoline harms the environment in the form of pollution and on the health of lung, kidney, skin diseases, and changes in the lipid profile in the form of increased levels of low-density lipoprotein (LDL) which can increase the incidence of coronary and metabolic heart disease. This study aimed to determine the effect of gasoline exposure on LDL levels in human blood plasma starting with a study of experimental animals. The research method used is descriptive with a scoping review procedure by identifying, analyzing, and evaluating scientific papers according to inclusion and exclusion criteria and screening using eligibility criteria. The research results obtained ten articles from the initial number of 10,486 articles found from keywords. Ten PICO-compliant articles (Population: rats; Intervention: gasoline, lead or benzene; Comparison: rats not exposed to gasoline, lead or benzene; Results: LDL levels in blood plasma) showed increased plasma LDL levels in the group of rats exposed to gasoline, lead or benzene control group. This is due to oxidative stress from lead or benzene induction which suppresses antioxidant activity and increases reactive oxygen species in the body, resulting in liver injury, impaired lipoprotein metabolism. In the end, gasoline which has benzene or lead component causes an increase in plasma LDL levels. This study concludes that there is an effect of gasoline on LDL levels in rat blood plasma, and several components of gasoline that play a role, namely lead and benzene.
\end{abstract}

Keywords: Benzene, gasoline, lead, low-density lipoprotein

Received: 8 ...; Revised: ...; Accepted: ...; Published: ...

Koresponden: Yola Noveraz Nasa. Program Pendidikan Sarjana Kedokteran, Fakultas Kedokteran Universitas Islam Bandung, Jl. Tamansari no. 22 Kota Bandung, Indonesia. No. Hp: +6281912033863 Email:ynoveraznasa@gmail.com 


\section{Pendahuluan}

Pertumbuhan rata-rata konsumsi BBM sebesar 1,76\% per tahun dengan rata-rata konsumsi tiap tahunnya sebanyak 345,14 juta barel. Konsumsi BBM Indonesia didominasi oleh bensin dan minyak solar. Konsumsi bensin sejak tahun 2000 sampai 2014 mengalami peningkatan. Hal ini dikarenakan bensin digunakan untuk sektor transportasi dengan jumlah kendaraan bermotor setiap tahun mengalami peningkatan, dengan rata-rata peningkatan sebesar $14,85 \%$ sejak tahun 2000 sampai 2014 . $^{1}$

Bensin sangat berguna dalam sektor transportasi, akan tetapi bensin memiliki dampak negatif terhadap lingkungan yaitu berupa polusi dan terhadap kesehatan yaitu gangguan paru, ginjal, penyakit kulit, serta perubahan profil lipid berupa peningkatan kadar LDL (Low-density lipoprotein). LDL merupakan suatu transporter lipid di dalam darah, terdiri dari 75\% lipid dan $25 \%$ protein sehingga memiliki kepadatan yang tinggi. LDL didistribusikan ke sel dari berbagai jaringan melewati darah. LDL yang bersirkulasi dibutuhkan oleh sel dan kemudian ditangkap oleh reseptor yang spesifik, yaitu reseptor LDL (LDLR) (B-10o, E). Reseptor LDL terletak di bagian pits pada permukaan sel dengan kadar normal di darah kurang dari $70 \mathrm{mg} /$ dl. Peningkatan kadar LDL dapat meningkatkan angka kejadian penyakit jantung koroner (PJK) dan sindrom metabolik..$^{2,3}$

Beberapa penelitian menyebutkan bahwa bensin dapat menyebabkan peningkatan LDL dengan cara merusak hepatosit melalui peningkatan $\beta$-oksidasi asam lemak. Proses oksidatif ini menghasilkan elektron bebas, $\mathrm{H}_{2} \mathrm{O} 2$, dan reactive oxygen species (ROS) dalam tubuh, di sisi lain antioksidan endogen seperti glutheparone, alpha-lipoic acid (thioctic acid), coenzyme $Q$, ferritin, uric acid, bilirubin, metallothionein, L-carnitine, melatonin dan albumin akan menurun, kerusakan hepatosit dapat menyebabkan gangguan metabolisme lipid akibat gangguan integritas membran sel yang dapat menyebabkan beberapa membran lipid akan dilepaskan ke dalam sirkulasi serta menekan efektivitas dalam pengaturan metabolisme lipid sehingga dapat meningkatkan kadar LDL (Lowdensity lipoprotein) di darah. Peningkatan kadar LDL (Low-density lipoprotein) di dalam darah dapat juga disebabkan oleh modifikasi kimia yang diakibatkan oleh ROS terhadap protein dan lipid pada LDL plasma yang menyebabkan pembentukan LDL yang abnormal sehingga tidak dikenali oleh reseptor LDL di hepar dan tidak dibersihkan oleh hepar..$^{4-6}$

Bensin terdiri dari komponen utama dan tambahan. Beberapa komponen bensin yang sangat toksik adalah lead dan benzene. Beberapa penelitian menunjukkan bahwa lead dan benzene dapat menekan aktivitas antioksidan dan meningkatkan ROS (reactive oxygen species) di tubuh yang mengakibatkan cidera pada hepar, pada akhirnya metabolisme lipoprotein terganggu. $4,7,8$

Penelitian ini dilakukan untuk mengetahui pengaruh paparan bensin terhadap kadar LDL pada plasma darah manusia yang dimulai dengan kajian terhadap hewan coba menggunakan metode deskriptif dengan prosedur scoping review.

\section{Metode}

Penelitian yang digunakan adalah Scoping Review mengenai pengaruh bensin terhadap peningkatan kadar LDL pada plasma darah tikus. Populasi dalam penelitian ini berupa jurnal nasional dan jurnal internasional yang berkaitan dengan pengaruh komponen pada bensin terhadap kadar LDL pada plasma darah tikus. Sampel dalam penelitian ini berjumlah sepuluh artikel penelitian dari jurnal nasional dan internasional yang berkaitan dengan judul penelitian yang sesuai dengan kriteria inklusi dan eksklusi. Kriteria inklusi pada penelitian ini adalah artikel penelitian yang dipublikasikan pada jurnal nasional dan internasional yang berkaitan dengan pengaruh bensin terhadap kadar LDL (Low-density lipoprotein) tikus dengan kata kunci seperti pada tabel 1, artikel dari tahun 2010 - 2020, tipe artikel penelitian original research articles (true experimental), artikel penelitian yang dapat diakses penuh (full text), artikel berbahasa Inggris dan Indonesia.

Tabel 1. Kata Kunci pada Database

\begin{tabular}{ll}
\hline Database: & Keywords dan Query \\
\hline SpringerLink & $\begin{array}{l}\text { Gasoline AND Low density } \\
\text { lipoprotein }\end{array}$ \\
ProQuest & $\begin{array}{l}\text { Gasoline AND Low density } \\
\text { lipoprotein }\end{array}$ \\
Google Scholar & (gasoline) OR (petrol) OR \\
& (benzene) OR (lead) OR \\
& $\begin{array}{l}\text { (oxidative stress) AND (lipid } \\
\text { profile) OR (low density }\end{array}$ \\
& lipoprotein) OR (LDL-C) AND \\
& $\begin{array}{l}\text { TANPA KATA (buku, book, } \\
\text { chicken, cross-sectional, case- } \\
\text { control, meeting, statement) }\end{array}$ \\
& Gasoline AND LDL Cholesterol \\
North American & \\
Journal of Medical & \\
Sciences & Gasoline AND LDL Cholesterol \\
Science Direct &
\end{tabular}

Hasil pencarian artikel-artikel dari kelima database tersebut akan disaring mengikuti alur PRISMA yang tertera pada Gambar 1. Total pencarian artikel pada database tersebut sejumlah 10.486 artikel. Setelah melalui penyaringan dengan kriteria inklusi didapatkan 290 artikel. Artikel eligible dipilih berdasarkan kriteria population, intervention, comparison, dan outcome (PICO). Kriteria PICO yang dipilih pada penelitian ini yaitu population berupa tikus, intervention yang diberikan bensin, lead atau benzene, comparison berupa tikus yang tidak dipaparkan bensin, lead atau benzene, hasil yang dianalisis adalah kadar LDL pada plasma darah tikus. Sejumlah sepuluh artikel eligible didapatkan setelah tahap penyaringan menggunakan kriteria PICO. 


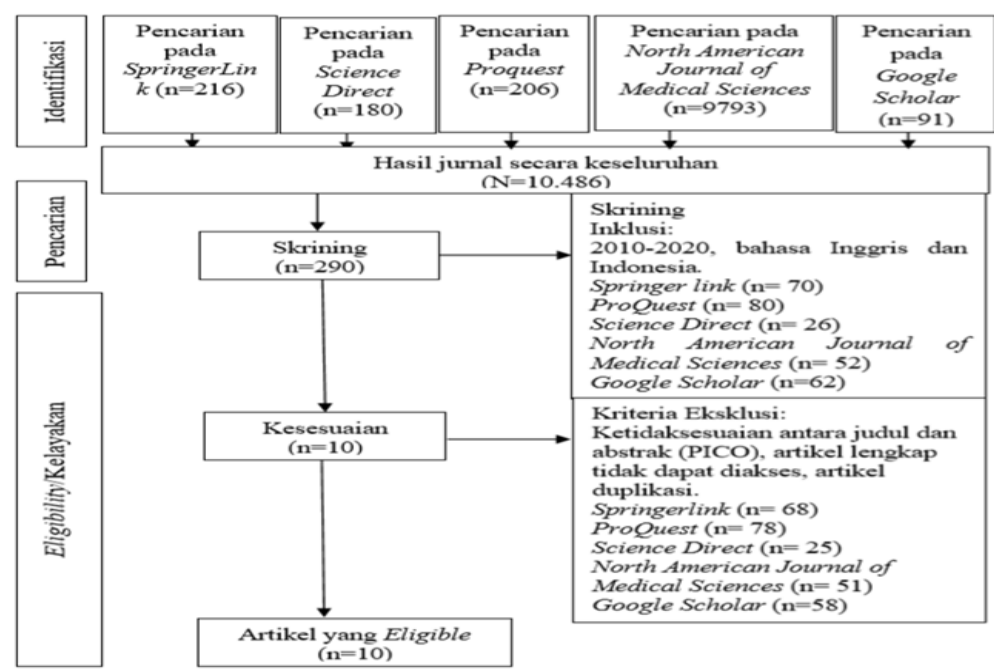

Gambar 1. Tahapan pencarian dan seleksi artikel hingga menjadi artikel yang di-review

\section{Hasil}

Tabel 2. Hasil Penelusuran Artikel Pengaruh Bensin terhadap Peningkatan Kadar LDL pada Plasma Darah Tikus

\begin{tabular}{|c|c|}
\hline Reference & Metode \\
\hline $\begin{array}{l}\text { Dr. Christopher E. } \\
\text { Ekpenyong, Samson A. } \\
\text { Oyebadej9 }\end{array}$ & $\begin{array}{l}\text { Kadar low density lipoprotein cholesterol (LDL-C) } \\
\text { serum ditentukan menggunakan multi-channel } \\
\text { automated system (Lipid pro TM, Model KM-Oo1A } \\
\text { Info Pia Co, Ltd. South Korea) }\end{array}$ \\
\hline $\begin{array}{l}\text { Mohy E. Abdel Fattah, } \\
\text { Hanan M. Sobhy, } \\
\text { Areeg Reda, Heba M. } \\
\text { A. Abdelrazek }{ }^{10}\end{array}$ & $\begin{array}{l}\text { Sampel diambil dari retro orbital venous plexus; LD } \\
\text { dikalkulasikan dengan rumus Friedwald: Serum LDI } \\
\mathrm{C}(\mathrm{mg} / \mathrm{dL})=\mathrm{TC}-(\mathrm{TG} / 5+\mathrm{HDL}-\mathrm{C}) \text {. }\end{array}$ \\
\hline $\begin{array}{l}\text { Honglin Sun, Ningjian } \\
\text { Wang, Xiaomin Nie, } \\
\text { Li Zhao, Qin Li, Zhen } \\
\text { Cang dkk } \mathbf{k}^{11}\end{array}$ & $\begin{array}{l}\text { Darah diambil dari vena caudal ekor setelah puasa } \\
\text { semalam pada akhir eksperimen; Deteksi kolesterol } \\
\text { LDL (low-density lipoprotein) dideteksi dengan } \\
\text { Siemens Dimension MAX (Siemens Healthcare } \\
\text { Diagnostics Inc) }\end{array}$ \\
\hline
\end{tabular}

Abeer E. Abdrabouh ${ }^{12} \quad$ Kit spinreact (Ctra Santa Coloma, Spanyol) digunakan untuk estimasi low-density lipoprotein (LDL)

Aysha A. Alshareef, Estimasi kadar low-density lipoprotein cholesterol Maha Ibrahim ${ }^{13}$ (LDL-C) menggunakan chemistry Reflotron kits [Roche, Reflotron plus 5080634, Germany].

A. Sedky, H. Elsawy ${ }^{14}$

Darah diambil dari retro-orbital sinus mata untuk analisis hematologis; Kadar LDL-cholesterol (LDL-C) dikalkulasikan menggunakan rumus Friedewald, satuan menggunakan $\mathrm{mg} / \mathrm{dL}$.
Kelompok yang dipaparkan bensin memiliki kadar LDL lebih tinggi secara signifikan $(\mathrm{p}<0,05)$ daripada kelompok kontrol normal

Kelompok lead acetate menunjukkan peningkatan yang signifikan $(\mathrm{P}<0,05)$ pada nilai total kolesterol, trigliserida, kolesterol LDL dengan penurunan yang signifikan $(\mathrm{P}<\mathrm{O}, 05)$ pada kadar kolesterol HDL ketika dibandingkan terhadap kelompok kontrol;

Pada kelompok NCD+0,05\% menunjukkan kadar LDL lebih tinggi daripada kelompok kontrol NCD (Normal chow diet $)(\mathrm{P}<0,05)$. 
Heba M. Abdou, Serum low-density lipoprotein (LDL-C) ditentukan
MohamedA. Hassan ${ }^{15}$ Eugenio 5-20155 Milan, Italia).
Pada data ini terdapat LDL-C serum yang meningkat secara signifikan $(\mathrm{p}<0,05)$ dengan pemberian lead acetate.

Cha-Min Liu, Jie- Kadar LDL serum diukur menggunakan standard Pemberian timbal secara signifikan Qiong Ma, Yun-Zhi enzymatic assays (Sigma Chemical Co., St. Louis, MO, $\operatorname{Sun}^{16}$ $U S A) .{ }^{16}$

meningkatkan kadar LDL dalam serum pada tikus yang diberi timbal sebesar 1,78 kali

lipat $(38,46 \pm 2,23)$ dibandingkan kelompok kontrol $(21,63 \pm 0,69, \mathrm{p}<0,01)$

Adegoke O. A., Kolesterol LDL diukur menggunakan metode enzimatik George Opuda I. M., (colorimetric). Diukur menggunakan metode yang

Bamigbowu E.O, dijelaskan oleh Friedewald. Ditentukan dengan

Ugbala J. $\mathrm{E}^{17} \quad$ perkalian absorbance of test dengan konsentrasi standar dan dibagi dengan absorbance of standard. ${ }^{17}$

Ogbevire L. Aberare, - Sampel diarah diambil melalui cardiac puncture; Patrick Okuonghae, - Konsentrasi plasma LDL-C diukur menggunakan Nathaniel Mukoro1, metode spectrophotometric;

John O. Dirisu, Favour - Laboratory kit reagents (Randox Laboratory

Osazuwa, Elvis Odigie Ltd, UK) digunakan untuk seluruh analisis biokimia $\mathrm{dkk}^{4}$ dan absorbannya dibaca menggunakan UV-Vis spectrophotometer (DREL $3000 \mathrm{HACH})^{4}$
Kolesterol LDL (Mmol/l) adalah $0,58 \pm$ 0,08 pada kelompok kontrol dan $0,68 \pm$ o,o5 pada kelompok yang terpapar asap bensin.

Peningkatan yang signifikan pada ratarata kadar kolesterol LDL diamati pada kelompok uji bila dibandingkan dengan kelompok kontrol dalam penelitian.
Pencarian literatur dilakukan dengan memilih database yang diambil dari artikel yang dipublikasikan pada SpringerLink, ProQuest, Science Direct, North American Journal of Medical Sciences, Google Scholar didapatkan pada awal pencarian 10.486 artikel, setelah di-filter menggunakan kriteria inklusi menjadi 290 artikel yang diidentifikasi dan dihilangkan artikel yang terdapat duplikasi 14 artikel maka menjadi 276 artikel. Pada 276 artikel tersebut dilakukan skrining berdasarkan kriteria kelayakan yaitu analisis kesesuaian PICO (Population), Intervention (intervensi atau perlakuan), Comparation (perbandingan atau control bila ada), Outcome (luaran) yang sesuai dengan penelitian yang dilakukan yaitu penelitian yang berjudul pengaruh bensin terhadap peningkatan kadar LDL pada plasma darah tikus. Pada penelitian ini populasi yaitu tikus, intervensi berupa bensin, lead atau benzene, perbandingan berupa tikus yang tidak dipaparkan bensin, lead atau benzene, dan luaran yang dianalisis berupa kadar LDL (low-density lipoprotein) pada plasma darah. Setelah dilakukan analisis PICO maka artikel yang sesuai yaitu sepuluh artikel. Sepuluh artikel yang di-review tersebut didapatkan dengan metode true experimental. Hasil penelitian berisi uraian artikel penelitian yang telah di-review (sejumlah artikel yang termasuk kriteria eligible pada PRISMA dan disajikan dalam bentuk tabel 2).

\section{Pembahasan}

Penelitian mengenai pengaruh bensin terhadap peningkatan kadar LDL (Low-density lipoprotein) pada plasma darah tikus sesuai dengan 10 artikel yang telah dikaji berdasarkan kriteria kelayakan (eligible). Komparasi berupa kelompok tikus kontrol untuk menginvestigasi perbandingan kadar LDL (Low-density lipoprotein) pada plasma darah sebagai outcome. Hasil penelitian dari artikel yang telah dikaji yaitu penelitian yang dilakukan oleh Christopher EE et al.(2016) dari SpringerLink, A. Sedky et al.(2015), Adegoke OA et al.(2020) Abeer E. Abdrabouh (2019) dari database Google Scholar, dan Aberare OL et al.(2011) dari database North American Journal of Medical Sciences menunjukkan pengaruh yang signifikan dari paparan bensin terhadap kadar LDL pada plasma darah tikus apabila dibandingkan dengan kelompok kontrol.4,9,12,14,17

Pada 10 artikel yang telah dikaji, 4 artikel menunjukkan peningkatan kadar LDL pada plasma darah tikus yang diinduksi oleh lead yang merupakan salah satu komponen bensin dibandingkan dengan kelompok kontrol pada penelitian yang dilakukan oleh Mohy E. Abdel Fattah et al. (2020) dari database SpringerLink, Honglin Sun et al.(2017), H.M. Abdou et al. (2014) dari database ProQuest, dan C.M. Liu et al. (2011) dari Science Direct. Komponen bensin lain, yaitu benzene dianalisis pada 1 artikel dari 10 artikel yang telah dikaji berupa penelitian yang dilakukan oleh Aysha A. Alshareef et al. (2020) dari database Google Scholar menunjukkan pengaruh terhadap peningkatan kadar LDL (Low-density lipoprotein) pada plasma darah tikus dibandingkan dengan kadar LDL pada plasma darah dalam kelompok tikus kontrol..$^{10,11,13,15,16}$

Hasil tersebut dapat diakibatkan oleh proses stres oksidatif yang diinduksi lead atau benzene yang menekan aktivitas antioksidan dan meningkatkan ROS (reactive oxygen species) di tubuh yang mengakibatkan cidera pada hepar, pada akhirnya metabolisme lipoprotein terganggu. Lead juga menghambat jalur utama LDL (Low-density liporprotein) clearance dari plasma dengan menurunkan ekspresi LDL-R (Lowdensity lipoprotein receptor) pada hepar. Berdasarkan penjelasan sebelumnya dapat diketahui bahwa bensin yang memiliki komponen benzene atau lead dapat mengakibatkan peningkatan kadar LDL plasma. ${ }^{16,18,19}$

Terdapat 5 artikel dari 10 artikel yang telah dikaji menunjukkan pengaruh bensin terhadap peningkatan kadar LDL (low-density lipoprotein), 4 artikel menunjukkan pengaruh lead terhadap peningkatan 
kadar LDL dan 1 artikel menunjukkan pengaruh benzene terhadap peningkatan kadar LDL pada plasma darah. Logam $\mathrm{Pb}$ yang terkandung dalam bensin sangat berbahaya, karena pembakaran bensin akan mengemisikan 0,09 gram timbal tiap $1 \mathrm{~km}$. Sekitar 25\% logam berat Timbal $(\mathrm{Pb})$ tetap berada dalam mesin dan $75 \%$ lainnya akan mencemari udara sebagai asap knalpot, sementara benzena sebagian besar digunakan sebagai komponen gasoline (bensin sebagai bahan bakar bermotor), dengan konsentrasi rata-rata kurang dari 1\%, sehingga dapat disimpulkan bahwa komponen bensin yang lebih berpotensi membahayakan berdasarkan kajian ini yaitu lead atau timbal. Penelitian yang dilakukan oleh Cristopher EE et al. (2016) pada database Google Scholar menunjukkan peningkatan kadar LDL plasma darah pada kelompok tikus yang dipaparkan bensin yang tidak mengandung lead daripada kelompok kontrol. Sehingga dapat disimpulkan juga bahwa bensin dapat meningkatkan kadar LDL (low-density lipoprotein) walaupun tanpa lead. ${ }^{9,20,21}$

Bensin dapat meningkatkan kadar kolesterol LDL akibat reaksi oksidatif yang dihasilkannya, proses ini melalui inaktivasi dari enzim metabolik dan merusak komponen penting selular dan oksidasi asam nukleat. Hal tersebut berhubungan dengan gangguan protein, asam nukleat, karbohidrat, dan metabolisme lipid yang menyebabkan perubahan homeostasis intraselular dan ekstraselular dan kehilangan secara bertahap dari integritas sel, fungsi enzim, dan stabilitas genomik. Dislipidemia yang diakibatkan oleh uap bensin diakibatkan toksisitas hepar, dari fungsi hepar pada metabolisme lipid dan homeostasis. Peningkatan kadar LDL akibat bensin juga dapat diakibatkan oleh kerusakan selular yang menyebabkan release bentuk berbeda dari lipid sebagai hasil dari disfungsi metabolisme yang berhubungan dengan membran selular yang abnormal sebagai akibat dari paparan komponen hidrokarbon dari bensin.9,12

Intoksikasi lead acetate secara signifikan meningkatkan kadar LDL-C pada kelompok tikus perlakuan dibandingkan kelompok tikus kontrol. Hal ini dapat diakibatkan penurunan removal dari lipoprotein, meningkatnya sintesis lipoprotein, atau supresi dari aktivitas lipoprotein lipase. Lead terbukti menekan aktivitas sitokrom P-450 yang membatasi biosintesis bile acid yang hanya menonjol pada rute eliminasi kolesterol dari tubuh. Benzene merupakan salah satu komponen BTX (Benzene, Toluene, Xylene) yang berpotensi menghasilkan reactive oxygen species (ROS), dimediasi oleh sitokrom p-450 hepar yang dikonversi menjadi fenol dan hydroquinone yang menyebabkan ketidakseimbangan antara status oksidan dan antioksidan dan meningkatkan stress oksidatif, proses ini pada akhirnya akan meningkatkan dari kadar LDL pada plasma darah..$^{10,12}$

Bensin beserta komponen toksiknya termasuk lead dan benzene merupakan xenobiotic. Xenobiotic merupakan bahan kimia yang masuk ke dalam tubuh dari sumber asing atau eksternal. Paparan kimia dibagi menjadi empat kategori, kategori paparan akut ketika intoksikasi kimia berlangsung 24 jam atau kurang, berdasarkan substansi spesifiknya tanda klinis dari intoksikasi akut memiliki gejala kelelahan, mudah marah, sakit kepala, delirium, kebingungan, muntah, diare, kram otot, kejang bahkan kematian. Intoksikasi subakut merupakan toksisitas yang ditandai setelah paparan berulang dari bahan kimia selama beberapa hari atau lebih dari 1 bulan. Paparan subkronis terkait dengan paparan terhadap kimia yang sedang berlangsung dan berulang selama periode 1-3 bulan jika dijumlahkan. Paparan kimia disebut kronis apabila paparan berlangsung 3 bulan atau lebih, pada penelitian ini menunjukkan paparan dari subkronis terhadap bensin dan lead dapat menyebabkan peningkatan kadar LDL (Low-density lipoprotein) tikus, sedangkan paparan benzena dapat meningkatkan kadar LDL tikus dalam paparan subakut. ${ }^{22}$

Penelitian lain menunjukkan terdapat pengaruh bensin terhadap peningkatan kadar LDL (low-density lipoprotein) pada plasma darah tikus dilakukan juga oleh Friday E. Uboh et al.(2011). Terdapat penelitian lain terhadap peningkatan kadar LDL (low-density lipoprotein) pada plasma darah tikus akibat paparan lead yang dilakukan oleh Adeyemi et al.(2020), Maha Mohamaed Essam El-Din (2015), dan Ugwuja et al.(2020). ${ }^{19,23-25}$

\section{Keterbatasan Penelitian}

Pada penelitian ini pencarian artikel hanya menggunakan lima database yaitu SpringerLink, ProQuest, Science Direct, North American Journal of Medical Sciences, dan Google Scholar, sehingga hanya didapatkan 10 jurnal yang berhubungan dengan pengaruh bensin terhadap kadar LDL (low-density lipoprotein) pada plasma darah tikus, sehingga perlu dilakukan pencarian artikel pada database lain.

\section{Simpulan}

Paparan bensin pada kelompok tikus perlakuan memiliki peningkatan kadar LDL yang signifikan daripada kelompok tikus kontrol. Oleh sebab itu, dapat disimpulkan bahwa paparan bensin dapat meningkatkan kadar LDL tikus. Paparan lead dan benzene menyebabkan peningkatan kadar LDL pada kelompok tikus perlakuan dibandingkan dengan kelompok tikus kontrol. Sehingga dapat disimpulkan bahwa, komponen bensin yang berpengaruh terhadap peningkatan kadar LDL tikus yaitu lead dan benzene.

\section{Ucapan Terima Kasih}

Ucapan terima kasih juga penulis sampaikan kepada orang tua dan dosen pembimbing atas segala bantuan, bimbingan, ilmu, nasehat, dukungan, doa, waktu, dan saran yang telah diberikan kepada penulis sehingga penulis dapat menyelesaikan skripsi ini.

\section{Konflik Kepentingan}

Tim peneliti tidak memiliki konflik kepentingan. 


\section{Daftar Pustaka}

1. Sa'adah AF, Fauzi A, Juanda B. Peramalan Penyediaan dan Konsumsi Bahan Bakar Minyak Indonesia dengan Model Sistem Dinamik. J Ekon dan Pembang Indones. 2017.

2. VanPutte C, Regan J, Russo A, Tate P, Stephens T, Seeley R. Seeley's anatomy and physiology. Professional Educator. 2013.

3. Prawiradilaga RS, Shahib $\mathrm{MN}$, Fatimah SN. Perbedaan Efek Infusa Bubuk Kedelai (Glycine max), Jamur Tiram (Pleurotus ostreatus), dan Campuran Keduanya terhadap Kadar Kolesterol LDL, Ekspresi Gen Reseptor LDL Hati, dan Berat Omentum Majus Mencit Model Hiperlipidemia. Glob Med Heal Commun. 2016.

4. Aberare OL, Okuonghae P, Mukoro N, Dirisu JO, Osazuwa F, Odigie E, et al. Triglycerides, total cholesterol, high density lipoprotein cholesterol and low density lipoprotein cholesterol in rats exposed to premium motor spirit fumes. N Am J Med Sci. 2011.

5. Rizzo AM, Berselli P, Zava S, Montorfano G, Negroni M, Corsetto P, et al. Endogenous antioxidants and radical scavengers. Adv Exp Med Biol. 2010.

6. urray RK, Granner DK, Mayes PA, Rodwell VW. Harper's Illustrated Biochemistry (31st Edition). Biochemical Education. 2018.

7. D'souza HS, Dsouza SA, Menezes G, Venkatesh T. Diagnosis, evaluation, and treatment of lead poisoning in general population. Indian $\mathrm{J}$ Clin Biochem. 2011.

8. Bonfim RR, Alves MIR, Antoniosi Filho NR. FastHRGC method for quantitative determination of benzene in gasoline. Fuel. 2012.

9. Cymbopogon citratus Stapf ( DC ) extracts alleviate gasoline vapour-induced metabolic disorders and cardiovascular disease risk in rats. 2016;160-9.

10. Abdel Fattah ME, Sobhy HM, Reda A, Abdelrazek HMA. Hepatoprotective effect of Moringa oleifera leaves aquatic extract against lead acetateinduced liver injury in male Wistar rats. Environ Sci Pollut Res. 2020;27(34):43028-43.

11. Sun H, Wang N, Nie X, Zhao L, Li Q, Cang Z, et al. Lead exposure induces weight gain in adult rats, accompanied by DNA hypermethylation. PLoS One. 2017;12(1):1-13.

12. Abdrabouh AE. Liver disorders related to exposure to gasoline fumes in male rats and role of fenugreek seed supplementation. Environ Sci Pollut Res. 2019;26(9):8949-57.
13. Alshareef AA, Ibrahim M. Neurological and Biological Toxicity of Subchronic Exposure to Benzene in Male Rats Aysha A . Alshareef and Maha Ibrahim. 2020;11:52-9.

14. Sedky A, Elsawy H. Protective Effect of Vitamins $\mathrm{C}$ and $\mathrm{E}$ against Gasoline Vapors Induced Haematological and Biochemical Changes in Male Rats. J Sci Res. 2015;7(3):139-49.

15. Abdou HM, Hassan MA. Protective role of omega-3 polyunsaturated fatty acid against lead acetate-induced toxicity in liver and kidney of female rats. Biomed Res Int. 2014;2014.

16. Liu CM, Ma JQ, Sun YZ. Protective role of puerarin on lead-induced alterations of the hepatic glutathione antioxidant system and hyperlipidemia in rats. Food Chem Toxicol [Internet]. 2011;49(12):3119-27.

17. Adegoke OA, M GOI, Bamigbowu EO, Ugbala JE. Evaluation of Lipid Profile in Male Albino rats exposed to petrol fumes. 2020;(July).

18. Mchale CM, Zhang L, Smith MT. Current understanding of the mechanism of benzeneinduced leukemia in humans: Implications for risk assessment. Carcinogenesis. 2012.

19. Adeyemi WJ, Abdussalam TA, Abdulrahim A, Olayaki LA. Elevated, sustained, and yet reversible biotoxicity effects of lead on cessation of exposure: Melatonin is a potent therapeutic option. Toxicol Ind Health. 2020.

20. Gusnita D. Pencemaran logam berat timbal (pb) di udara dan upaya penghapusan bensin bertimbal. Ber Dirgant. 2012.

21. Winata SD. Dampak dan Monitoring pada Pekerja Terpapar Benzena. J Fak Kedokt Ukrida. 2015.

22. Burcham PC. An introduction to toxicology. Vol. 9781447155, An Introduction to Toxicology. 2014. $1-327 \mathrm{p}$

23. Uboh FE, Akpanabiatu MI, Ebong PE, Essien EU. Effect of vitamins $\mathrm{A}$ and $\mathrm{E}$ on gasoline vapours induced atherosclerosis in male rats. Int $\mathrm{J}$ Pharmacol. 2011.

24. Mohamed Essam El-Din M. The potential role of flaxseeds on hyperlipidemia, oxidative stress and toxicity induced by lead acetate in adult male albino rats. 2015;31(31):51-70.

25. Ugwuja EI, Vincent N, Ikaraoha IC, Ohayi SR. Zinc ameliorates lead toxicity by reducing body $\mathrm{Pb}$ burden and restoring $\mathrm{Pb}$-induced haematological and biochemical derangements. Toxicol Res Appl. 2020;4:239784732095656. 